\section{Nyttig om etikk i praksis}

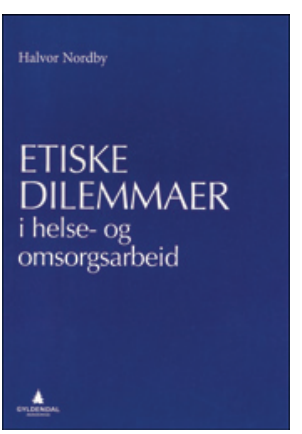

Halvor Nordby

Etiske dilemmaer i helse- og omsorgsarbeid

202 s, ill. Oslo: Gyldendal Akademisk, 2012

Pris NOK 299

ISBN 978-82-05-41949-0

Boken presenteres som en lærebok beregnet spesielt på grunn-, videre- og etterutdanning innen helse- og omsorgsfagene. Forfatteren tar spesielt sikte på å utdype og klargjøre etiske dilemmaer som de profesjonelle kan møte ansikt til ansikt med dem som søker hjelp. Men også lederes utfordringer i etikkfeltet berøres i noen grad.

Et overordnet tema er det krysspresset profesjonelle innen helse og omsorg ofte kan stå i, mellom krav og forventninger fra en ledelse styrt av en økonomi- og administrasjonstenkning, inspirert av New Public Management (NPM), og egne etiske vurderinger og prioriteringer i møter med pasienter i det daglige arbeidet. Forfatteren tar også opp forventningspresset fra pasienter og pårørende som noen ganger - mer eller mindre uttalt - kan sette yrkesutøverens etiske vurderingsevne på prøve.

Til hjelp for klargjøring av problemstillinger og valg i ulike situasjoner presenterer forfatteren en bred og godt forståelig gjennomgang av ulike etiske og filosofiske posisjoner som kan være aktuelle for praksis. Deretter beskriver han modeller for diskusjon, refleksjon og beslutningsstøtte i tilsynelatende uløselige dilemmaer for den enkelte yrkesutøver. Refleksjon over praksis presenteres som et helt nødvendig tiltak i enhver klinisk enhet, noen ganger uformelt kolleger imellom, andre ganger initiert av nærmeste leder for alle medarbeiderne $\mathrm{i}$ enheten.

Presentasjonen av kliniske eksempler fra daglig praksis på sykehjem, i ambulansetjeneste, sykehus og hjemmetjeneste øker tilgjengeligheten til stoffet og virker inspirerende selv for en erfaren kliniker. Forfatteren har ikke fokusert spesielt på legers etiske dilemmaer i helsetjenesten. Likevel vil stoffet i høy grad ha relevans både for medisinstudenter og erfarne leger i og utenfor sykehus. Jeg anbefaler boken både for selvstudium og som refleksjonsstøtte i kollegagrupper.

Eli Berg

Universitetet i Oslo, campus Ahus

\section{Hvor hardt skal leger lete etter sykdom hos friske?}

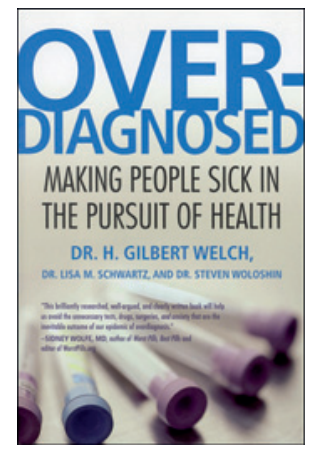

H. Gilbert Welch, Lisa M. Schwartz,

Steven Woloshin

Overdiagnosed

Making people sick in the pursuit of health. 228 s, tab, ill. Boston, MA: Beacon Press, 2011. Pris USD 25

ISBN 978-0-8070-2200-9

I 2004 skrev Gilbert Welch boken Should I be tested for cancer? Maybe not and here is why. Denne nye, Overdiagnosed, kan ses på som en oppfølger. Han problematiserer det medisinske dogmet om at «jo tidligere diagnostisering av en sykdom, desto bedre helse». Ifølge Welch er overdiagnostikk ikke bare «for mange diagnoser», men at et individ blir diagnostisert med en tilstand som aldri ville gitt symptomer eller ført til død. Forfatteren presiserer at dette ikke er en bok om hva man skal gjøre når man er syk. Målgruppen er de friske eller de som har en sykdom, og som har risiko for å bli fortalt at de har flere.

Forfatteren henvender seg til både leg og lærd. Boken er velskrevet og lettlest uten at det går på bekostning av det faglige. Teksten er illustrert med gode kasuistikker, figurer og tabeller. Uttalelser er belagt med referanser for å støtte forfatterens konklusjon om at tidlig oppdagelse av sykdom ikke alltid er et gode.

Det er konseptuelt vanskelig å forstå at å oppdage et symptom som kan føre til sykdom, eller sykdom på et tidlig stadium, kan være en ulempe og i visse fall være direkte skadelig. Vi er opplært til å tenke at det er om å gjøre å oppdage alt tidlig, slik at vi kan forhindre sykdom eller død. Hvorfor er da det ikke bare bra å stille en diagnose tidlig?

$\AA$ gi et svar på dette er en pedagogisk utfordring, som Welch løser bra. Han starter med å gi flere eksempler på hvordan vi forskyver grensene for hva som er normalt, og at dette som regel fører til at flere får en diagnose og dermed behandling. Ved å senke grensen for fastende blodsukker fra 7,8 til 7,0, mmol/l fikk over 1,5 millioner flere amerikanere diabetes mellitus. Når grensene for hva som er normalt, senkes, vil flere bli syke og dermed få behandling. Balansen mellom fordeler (for dem som unngår å få eller dø av hjerteinfarkt eller slag) og ulemper (ved å være syke og få behandling for dem som aldri ville fått eller dødd av hjerteinfarkt/slag) forrykkes. Flere vil dermed unødvendig behandles for at én skal ha fordel av behandlingen. Det fører til overdiagnostikk.

Det er vanskeligere å forstå overdiagnostikk ved kreft. Hvordan kan det være noen ulemper ved å oppdage kreft tidlig? Les boken og få innblikk i hvordan vi kan misledes til å tro at bare man oppdager «noe» tidlig nok, blir man bra. Medisinsk evidens taler imot et slikt dogme.

Mette Kalager

Sykehuset Telemark

og

Harvard School of Public Health 